\title{
Preventing bullying: Peer culture as the crucial developmental context in adolescence
}

\author{
Katja Košir \\ Faculty of Arts, University of Maribor, Slovenia
}

\section{Abstract}

Bullying is a phenomenon inevitably embedded in a group context; it is defined by and reflects the broader classroom peer dynamics. The present article aims to review and synthesise current scientific conceptualisations and findings regarding bullying dynamics in adolescence. The multi-level nature of factors that contribute to bullying is presented with emphasis on classroom-level factors. The characteristics of peer groups as students' crucial developmental contexts that co-determine the dynamics of bullying are presented. In addition, the special relevance of classroom factors of bullying in the Slovenian school system is explained. As also emphasised in the PYD perspective, it is argued that bullying can only be understood by investigating the interaction of characteristics of the individual with the characteristics of students' classrooms as their primary reference group.

Keywords: peers, bullying, classroom characteristics, prevention, inclusive peer culture

\section{Vrstniška skupina kot ključni razvojni kontekst v mladostništvu: \\ prikaz na primeru preprečevanja medvrstniškega nasilja \\ Povzetek}

Medvrstniško nasilje je pojav, ki je neizogibno vpet v skupinski kontekst, saj je določen s širšo razredno dinamiko in jo obenem odraža. Namen prispevka je povzeti in povezati sodobne znanstvene opredelitve in ugotovitve, 
vezane na dinamiko medvrstniškega nasilja v mladostništvu. S poudarkom na dejavnikih na ravni razreda prikažemo večnivojsko naravo dejavnikov medvrstniškega nasilja ter opredelimo tiste značilnosti vrstniških skupin kot ključnih razvojnih kontekstov mladostnikov, ki sodoločajo razvoj dinamike medvrstniškega nasilja. Ob tem še dodatno relevantnost usmerjanja pozornosti na dejavnike medvrstniškega nasilja na ravni razreda utemeljujemo s posebnostmi slovenskega izobraževalnega sistema. Zaključimo, da je za celostno razumevanje medvrstniškega nasilja ključno preučevanje interakcij med individualnimi značilnostmi učencev in značilnostmi razredov kot ključnih referenčnih skupin $\mathrm{v}$ obdobju šolanja, kar je tudi ena ključnih predpostavk modela pozitivnega razvoja mladih.

Ključne besede: vrstniki, medvrstniško nasilje, značilnosti razreda, preventive, vključujoča vrstniška kultura

\section{Introduction}

Bullying, defined as aggressive, goal-directed behaviour that harms another individual within the context of a power imbalance (Volk et al., 2017) is a complex phenomenon that is inevitably embedded in a group context since it reflects the nature of peer relationships within the classroom or in any other peer group. In addition, bullying reflects school-level attitudes, skills and policies associated with the enhancement of an inclusive peer culture and bullying prevention. This means that the classroomand school-level factors of bullying are crucial to a comprehensive understanding of bullying that provides the scientific background to bullying prevention. The present article reviews the results of studies that investigated the school- and classroom-level factors of bullying in Slovenia and abroad and places them in the context of the PYD model. Further, the role of an inclusive school- and classroom-level culture in bullying prevention is justified. As crucial developmental contexts for students, the peer group characteristics that co-determine the dynamics of bullying (and thereby bullying prevention) are presented. The main aim of this review is to outline current scientific conceptualisations and findings concerning bullying dynamics in adolescence and to highlight the role of systematic efforts in creating inclusive developmental contexts for adolescents and enhancing the stage-environment fit (Eccles et al., 1993) of adolescents' educational experiences. 


\section{Bullying: a brief overview}

Peer relationships are strong sources of joy, support and satisfaction yet also distress in all periods of schooling. During adolescence, the importance and impact of experiences in the peer context for students' well-being increases. The experience of peer victimisation is one of the biggest sources of distress that can happen within a peer context. Since bullying comes in many forms and the experience of the victim is the key criterion to determine whether an imbalance of power exists between perpetrator and victim, bullying can prove very difficult to recognise (Salmivalli et al., 2011). Understanding bullying as a phenomenon that reflects and co-shapes peer dynamics in the classroom can significantly enhance efforts to prevent and efficiently cope with bullying.

Bullying refers to a wide range of behaviours traditionally categorised as three distinct forms: physical (e.g. hitting, kicking, pushing), verbal (e.g. name-calling, threats) and relational bullying (e.g. social exclusion, spreading rumours) (e.g. Marsh et al. 2011; Menesini and Salmivalli 2017; Salmivalli et al., 200o). Recently, although cyberbullying has been added to this categorisation, scientific consensus on whether cyberbullying may be regarded as a distinctive form of bullying is still missing because this form of bullying contains many characteristics of verbal and relational bullying. Cyberbullying is typically defined as aggressive, intentional behaviour of a group or individual using electronic forms of contact over an individual who cannot easily defend him- or herself (Smith et al., 2008). The perpetrator can act anonymously, making it more difficult for the victim to report cyberbullying (DePaolis \& Williford, 2015). In addition, since cyberbullying is not limited to certain peer contexts, it can occur at any time of day or night (Kowalski et al. 2018); the audience can hypothetically be much larger than with traditional bullying (e.g. Nocentini et al., 2010). Yet, it should be noted that traditional bullying is a strong predictor of cyberbullying (e.g. Kowalski et al., 2014; Peras, 2019). This makes it reasonable to assume that prevention and intervention efforts in the area of traditional bullying by shaping an inclusive peer culture also help to prevent cyberbullying.

The term bullying refers to both bullying behaviour and victimisation; current conceptions of bullying consider victimisation and bullying behaviour as orthogonal dimensions (Menesini \& Salmivalli 2017; Sanders \& Phye 2004), whereas students can be high or low in both dimensions. Students low in both dimensions are conceptualised as bystanders and recognised as significant participants in the dynamics of bullying. 
Unlike initial conceptualisations that described bullying as an event usually occurring in a bully-victim dyadic relationship, typically in private or secret settings, contemporary studies (e.g. Bouman et al., 2012; Craig et al., 2000) show that bullying is mostly a public event with many participants; its influence reaches far beyond the relationship of bully and victim. The behaviour of bystanders (usually classmates) plays an important role in the occurrence and maintenance of bullying: their responses in bullying situations hold the potential to either prevent the bullying or intensify it. Students who bully are often motivated by the social power and status they gain from bullying (Olthof et al., 2011; Salmivalli, 2014). The reactions of peers as bystanders in bullying situations are those determining whether popularity and social status in the group can be achieved with the strategic use of bullying behaviour.

\section{The contextual factors as predictors and moderators of bullying}

Understanding the factors that predict bullying is crucial if we are to ensure the design of effective bullying prevention and intervention strategies. Victimisation and bullying behaviour are complex phenomena with a broad variety of factors that influence the probability of an individual being involved in the bullying process as either a victim or perpetrator. Previous studies (see Menesini \& Salmivalli, 2017) indicated that the level of an individual's victimisation and bullying behaviour may be predicted by various factors appearing on different levels - school, classroom and individual. Some students' individual characteristics, such as internalising problems and lack of peer support, were found to increase their vulnerability to victimisation (Cook et al., 2010; Kljakovic and Hunt, 2016, Košir et al., 2020). Among individual-level predictors of bullying behaviour, a strong desire for power and status and high perceived popularity has been consistently reported (Caravita et al., 2012; de Bruyn et al., 2010; Košir et al., 2020; Olthof et al., 2011; Sijtsema et al., 2009).

Further, the school environment can also significantly determine the frequency and intensity of bullying; certain school- and classroom-level characteristics were found to predict victimisation and bullying as well as moderate the relationship between individual-level characteristics and victimisation/bullying. Studies that have investigated the school-level factors of bullying provide quite diverse data on the share of variance in bullying explained by differences between schools (e.g. up to $2 \%$ in a sample of American adolescents, Bradshaw et al., 2009; $9 \%-15 \%$ in a sample of Israeli 
adolescents, Khoury-Kassabri et al., 2004; $2 \%-3 \%$ in a sample of Finnish adolescents, Saarento et al., 2013). Among school-level characteristics, the school climate with unclear disciplinary procedures and a higher proportion of boys at school (Khoury-Kassabri, 2004; Ma, 2002) were found to increase victimisation, whereas a positive school climate and a higher level of parental involvement (Ma, 2002) as well as students' perceptions of teachers' disapproving attitudes toward bullying (Saarento et al. 2013) were found to work as protective factors. The results of a study that investigated the predictors of victimisation and bullying on a large sample of Slovenian adolescents (Košir et al., 2020) revealed no significant differences between schools in levels of victimisation or bullying behaviour. Similarly, secondary analyses of data obtained in the international studies TIMSS 2011 and TIMSS 2015 indicated that only a small amount of variance in victimisation could be explained by the differences between schools $(18 \%-4 \%)$; this amount is smaller for older students (Košir \& Japelj Pavešič, 2020). It was also found that school size and the degree of problematic behaviour at school as reported by school principals do not predict victimisation.

Investigating the classroom-level factors of victimisation and bullying seems more promising. Previous studies (e.g. Garandeau et al., 2014; Košir et al., 202O; Pan et al., 2020; Saarento et al., 2013) showed that classroom-level factors (i.e. antibullying attitudes, teacher attitudes, outcome expectations when defending victims, strong classroom hierarchies) mostly explain around $10 \%$ of the variance in performing and experiencing bullying. These studies have identified certain classroom characteristics that predict bullying and victimisation. Among protective factors, classroom attitudes that do not approve of bullying and students' perception of disapproving teachers' attitudes toward bullying (Saarento et al., 3013) were reported. The expectation of negative social consequences when defending victims (Saarento et al., 2013), strong classroom pro-bully norms (Košir et al., 2020) and more salient classroom status hierarchies (Garandeau et al., 2014) were found to increase bullying and/or victimisation.

However, it is very likely these data underestimate the role of the classroom-level factors of bullying since some characteristics of classroom social dynamics are also characteristics traditionally viewed as being as students' individual characteristics (i.e. social acceptance, popularity), even though they are determined by the classroom's functioning. Thus, students' individual characteristics that are related to their peer relations should be regarded as characteristics that partly reflect the relationships and social 
processes in the peer group. The dimensions of constructs that reflect a student's position in a peer group provide information about the extent to which the student is (dis)liked or perceived as popular by the peer group members (Buhs and Ladd, 2001). While this is an individual measure, it depends on how the individual is evaluated by members of the reference group. Measures that assess students' peer relations based on peer nominations hence always also reflect the individual-group relationship (Cillessen, 2011b). In addition, this is partly true for self-report measures of students' peer relations as well (e.g. self-perceived peer support) as students' peer relations are established as an interaction between the characteristics of an individual and a group.

Understanding the relationship between the characteristics of classrooms as students' primary peer contexts and their individual characteristics is therefore essential if bullying prevention is to be effective. In the subsection below, the role of classroom context in bullying dynamics is described and explained, also regarding the specifics of the Slovenian school system.

\section{The classroom as the central peer context for bullying}

The classroom environment provides the main developmental context for students' social and emotional learning. Within the classroom, students compare themselves, establish relationships, form smaller groups, build their social position, as well as perform, experience and observe bullying (Pouwels et al., 2018). The findings showing that bullying is likely to be related to high popularity are particularly noteworthy since popular students are more likely to be regarded as models of adequate social functioning and as socially competent and can therefore act as significant socialising agents in students' social learning (the popularity effect; Cillessen, 2011a). This confirms that for effective bullying prevention it is essential to understand the relationship between the characteristics of classrooms as students' primary peer contexts and students' individual characteristics.

This is particularly important in the transition to adolescence - a developmental period that is - besides considerable changes in students' cognitive, social and emotional functioning - characterised by significant qualitative changes in the social dyna mics of bullying (Yeager et al., 2015). Alongside changes in the manifestation of bullying (an increase in relational and cyberbullying and a decrease in physical bullying), the changes in the underlying reasons for bullying and in the peer social dynamics that enable and 
maintain bullying are decisive in the transition to adolescence. The reasons for bullying behaviour and for bystanders' responses that maintain and enhance the bullying dynamics can usually be explained by changes in students' social motivation (high aspirations for popularity, power, and social status; see, e.g., van den Broek et al., 2016). Students who do not conform to the classroom norms can thus become victims of chronic bullying. Due to the growing influence that bullies have on bystanders, students who experience bullying become ever more socially isolated. Therefore, they suffer not only from bullying but also from social isolation and a lack of support within the classroom. This frequently leads to endorsing characterological self-blaming attributions - attributing victimisation to internal, uncontrollable and stable causes (i.e. self-blaming, attributing bullying experiences to the type of persons they are). Such attributions further add to the distress of the victimised and contribute to the continuation of victimisation (Juvonen \& Schacter, 2017). Such self-blaming attributions are more likely at schools with a lower level of overall victimisation; at schools with higher levels of victimisation, victims more likely attribute their bullying experiences to more controllable and less stable factors (e.g. 'being in the wrong place at the wrong time'; Schachter \& Juvonen, 2015). This finding again illustrates how bullying experiences (in this case, the social cognitions of victims) are embedded in the social context since they depend on the normativity of the experience in a certain environment (Juvonen \& Schacter, 2017). It is also consistent with the findings that classroom reductions in the share of victims who followed effective interventions can be harmful to students who remain victimised, as indicated by the increased depression and social anxiety among these stable victims (Garandeau et al., 2018).

In adolescents, the proportion of students who bully others and their reinforcers and assistants is higher than in childhood, while the share of those who defend victims drops (Pouwels et al., 2018). These findings are consistent with the predominant conceptualisation of bullying as goal-directed behaviour. In adolescence, social goals like peer status and popularity become increasingly important (e.g. LaFontana \& Cillessen, 2010). The more important these goals are for students, the more likely they use bullying behaviour or support such behaviour in popular bullies (e.g. Caravita \& Cillessen, 2012; van den Broek et al., 2016). This means the main reason that bystanders are more tolerant of bullying during adolescence is the importance of being acknowledged by one's peers in this period. To fully understand bullying during adolescence, it is hence vital to understand the perspective held by bullying bystanders. 


\section{Being a bystander of bullying}

Merely witnessing bullying is distressing; Nishina \& Juvonen (2005) report that students who had observed bullying over several days reported increased levels of anxiety and negative attitudes toward school. Yet, if bullying bystanders can therefore understand the victim's perspective and distress, why do only intervene in a small number of cases? Reasons for bystander passivity established in existing studies (e.g. Pöyhönen et al., 2010; Sentse et al., 2007) were mostly a fear of retaliation or threat to one's own social position and low self-efficacy for defending victims. Standing up for a victimised student and thus opposing the bully who is usually highly popular and influential involves social risk because it jeopardises the intervening student's own status. Therefore, observers tend to remain passive (bystander passivity). Perceiving that their peers are also remaining passive further reinforces their own passive attitude since students misinterpret this passivity - as if their peers approve the bullying. This reinforces the (non)response of the whole group (pluralistic ignorance; Miller \& Prentice, 1994) and enhances the bullying dynamics (Sandstrom et al., 2012). Another cognitive process that can account for the 'chronification' of bullying group dynamics is the phenomenon of moral disengagement (Bandura, 2002), defined as a cognitive mechanism whereby students convince themself that a behaviour that is contrary to their own moral standards is acceptable (Meter \& Bauman, 2018). This includes blaming the victim (»She deserved it!«), minimising the impact of bullying (»It's no big deal, it didn't really hurt them!«), displacing the responsibility (»It wasn't just me!«) etc. It is thus a socio-cognitive mechanism that enables students (bullies and the bystanders) to shut down any self-sanctions that would normally accompany the violation of one's own's moral standards (e.g. feelings of shame, guilt and negative self-evaluations). An association between moral disengagement and bullying behaviour was found in many studies (e.g. Gini et al., 2014; Meter \& Bauman, 2018; Runions et al., 2019); however, recently, researchers have also been able to confirm a relationship between moral disengagement and bystander passivity (e.g. Bussey et al., 2020; Thornberg et al., 2020).

The bullying classroom dynamic described above is not only unfavourable for the students who experience bullying; it is a problem for all students since it supports the learning of patterns of social behaviour that are exclusive and is hence completely the opposite to an inclusive school and classroom culture. The school or classroom environment represents a 
key context for the social and emotional learning of all students. It holds the potential to considerably shape the social behaviour of adolescents and, considering their developmental needs, supports behaviours that enable them to achieve their social goals in ways that do not involve bullying. Creating inclusive classroom contexts seems especially important in the Slovenian school system because students usually spend the entire period of elementary school (i.e. 9 years of schooling) in the same classroom environment. Potentially unfavourable social dynamics in the class peer group can therefore represent a very stable adverse developmental context.

\section{The classroom as a developmental context in Slovenia's school system}

The transition to adolescence is a developmental period characterised by declines in students' academic engagement (e.g. Gutman \& Midgley, 2000; Pintrich \& Schunk 2002) and in changes in their social functioning (Yeager et al., 2015). Many previous studies (see Roeser et al., 2000, for a comprehensive review) investigated the contextual factors that can contribute to changes in the academic and social behaviour of students as they transition to adolescence. These changes have been partly attributed to the transition to a new educational level (e.g. Eccles et al., 1993; Wentzel, 2009). Eccles et al. (1993) explained students' school adjustment using the term stage-environment fit. This concept derives from the model of person-environment fit theory in that it proposes that individuals do best in settings in which they fit well with the norms and aggregate characteristics of students and do less well in settings in which they are an outlier. It is also consistent with the relational developmental system theory (Overton, 2015), which emphasises the interplay of individual characteristics and contexts while arguing that students' behaviour and developmental outcomes should be studied as a product of the two-way interaction between the individual and their environment.

Given that contemporary conceptualisations of bullying strongly emphasise that the dynamic interplay of the characteristics of both the context and individual students is crucial for understanding the dynamics of bullying, studies investigating bullying within the PYD framework are surprisingly scarce. A basic assumption of the PYD model is that students will develop positively when their strengths are aligned with the resources in their social contexts (Lerner, 2017) and that this positive development will be reflected in more positive outcomes (e.g. intervening as a bystander in 
bullying situations) and in less unwanted or risky behaviours (e.g. using bullying to gain social power, reinforcing bullying as a bystander).

The studies that have considered bullying in the PYD framework have shown that students reporting higher levels of internal and external assets also reported lower levels of both bullying perpetration and victimisation (Benson \& Scales, 2009; Fredkove et al., 2019), indicating that developmental assets could work as protective factors for bullying involvement. In addition, the protective role of some internal (e.g. social competence, positive identity; Tsaousis, 2016; Zych et al.., 2019a)there are still many gaps in knowledge that need to be addressed. Research on protective factors and effective interventions is still in its relatively early stages. This systematic review of meta-analyses on protective factors against bullying and cyberbullying was conducted to synthesize knowledge and discover the most important community, school, family, peer and individual protective factors. After systematic searches and the application of inclusion and exclusion criteria, 18 meta-analyses with 128 effect sizes were included and analyzed. Forest plots were constructed and median effect sizes were calculated for each group of protective factors. Self-oriented personal competencies were the strongest protector against victimization. Low frequency of technology use protected from involvement in cyberbullying. Good academic performance and other-oriented social competencies were the strongest protective factors against perpetration. Positive peer interaction was the strongest protective factor against being a bully/victim. These findings can be useful to improve anti-bullying programs, policy and practice. Bullying perpetration and peer victimization has long been considered an important social and clinical problem. Children and adolescents who are bullied are at increased risk for mental health problems. The aim of this study was to investigate the relationship between self-esteem and bullying behavior (i.e. perpetration and peer victimization and external resources (e.g. peer and teacher support; Holt \& Espelage, 2007; Košir et al., 2020) has been found in studies that investigated these resources from theoretical perspectives other than PYD model. The same holds for the indicators of positive youth development that have been examined relative to bullying: care could also be conceptualised as empathy (Zych et al., 2019b), connection as peer support and friendships (Kenrtich et al., 2012, Košir et al., 2020) and competence as both academic and social competence (Jenkins et al., 2016).

In many countries, the transition from childhood to adolescence corresponds with the transition to a new level of education (from elementary 
to lower secondary school level), which implies entering a completely new school environment. Eccles and Roeser (2011) relied on the concept of stageenvironment fit to explain changes in students' academic and social functioning since most junior high schools are larger than elementary schools, and instruction is more likely to be organised departmentally. On the lower secondary education level, students are typically taught by many different teachers, which makes establishing close teacher-student relationships more difficult. This then substantially weakens teachers' influence and their ability to detect students' academic and/or social difficulties early on (e.g. Lee \& Smith, 2001). Moreover, students enter a new peer system that is likely to develop different, context-specific norms and collective values. Using the concept of stage-environment fit, Eccles and Roeser (2011) analysed relevant research findings concerning how: (1) teachers, curricular tasks, and classroom environments; (2) aspects of the school as an organisation; and (3) district policies and practices can play an instrumental role in adolescents' intellectual and social-emotional development.

However, the Slovenian school system is specific because elementary and lower level secondary education is organised at the same school (called basic school) from the age of 6 until the age of 15 . Compulsory basic education in Slovenia is organised as a single-structure (ISCED 1 and ISCED 2), 9-year basic school attended by pupils aged 6 to 15 years (Taštanoska, 2017). Thus, in our school system, emerging adolescents do not transit to another school. Nevertheless, their school experience gradually changes; from years 1 to 3, students are generally taught most subjects by their class teachers. In the fourth year of elementary education, teaching and school subject responsibilities gradually become divided among teachers, although in fourth and fifth grades the class teacher still teaches most subjects. During the whole elementary and secondary schooling period, a class teacher is assigned to every class. This class teacher teaches the students at least one subject. Accordingly, the transition on the lower secondary level is more gradual for Slovenian students. They experience changes in their teacher-student relationships and curricular tasks; nonetheless, this occurs in the context of their peer classroom environment. In Slovenian elementary schools, the law stipulates a maximum of 28 pupils per class. The average actual class size in 2018/2019 was 21 pupils (ISCED 1 and ISCED 2) (Taštanoska, 2020). This peer environment usually remains the same or its main structural characteristics are quite stable (although, of course, the psychosocial processes in peer relations change over the 9 years of schooling). Thus, creating 
inclusive classroom contexts seems especially important in the Slovenian school system as students usually spend the entire period of elementary school (i.e. 9 years) in the same classroom environment. Potentially unfavourable social dynamics in the class peer group (e.g. the aggressive popularity norms which enable a chronic bullying process; Laninga-Wijnen et al., 2019) can therefore create a very stable adverse developmental context.

\section{Conclusions and implications}

Studies that have investigated the factors of bullying behaviour in adolescence reveal that it is crucial to address the interaction between the aspirations of bullies and the characteristics of the peer environment that support the functionality of aggressive and bullying behaviour for gaining control over others (Rodkin et al., 2015). A comprehensive understanding and the sensitive addressing of students' social motives and the psychosocial characteristics of class contexts are thus very important while designing efficient preventive and intervention programmes for adolescents. Bullying can only be understood by investigating how the characteristics of the individual interact with the characteristics of students' classrooms as their primary reference group. This framework is consistent with the PYD perspective and is crucial for designing interventions for promoting inclusive classroom environments that enable all students to recognise their social needs and motives as valid and acceptable and teach them to aspire towards them in a respectful way. Such classroom environments are likely to prevent the development of aggressive popularity norms and thereby help adolescents to develop positive social behaviour. In addition, interventions should empower teachers to support adolescents' social and emotional learning and to moderate their peer relationships. In this respect, positive youth development programmes focused on establishing close relationships, encouraging resilience to negative (peer) influences, promoting social, emotional, cognitive and moral competence, encouraging self-determination and a clear identity, encouraging self-efficacy and endorsing prosocial norms (see e.g. Bonell et al., 2016; Catalano et al., 2004) seem especially relevant. Finally, future studies should address the effects of comprehensive bullying prevention and intervention programmes that would consider the developmental needs of adolescents and the developmental specifics of adolescents' peer groups in the Slovenian school system context. 
Acknowledgements

The article forms part of the project Positive Youth Development in Slovenia: Developmental pathways in the context of migration (PYD-SI Model; J51781), financially supported by the Slovenian Research Agency.

\section{References}

Bandura, A. (2002). Selective moral disengagement in the exercise of moral agency. Journal of Moral Education, 31(2), 101-119. https//doi. org/10.1080/0305724022014322

Benson, P. L. \& Scales, P. C. (2009). Positive youth development and the prevention of youth aggression and violence. International Journal of Developmental Sciences, 3(3), 218-234. https//doi.org/10.3233/ DEV-2009-3302

Bonell, C., Hinds, K., Dickson, K., Thomas, J., Fletcher, A., Murphy, S., ... Campbell, R. (2016). What is positive youth development and how might it reduce substance use and violence? A systematic review and synthesis of theoretical literature Health behavior, health promotion and society. BMC Public Health, 16(1). https//doi.org/10.1186/s12889-016-2817-3

Bouman, T., van der Meulen, M., Goossens, F. A., Olthof, T., Vermande, M. M., \& Aleva, E. A. (2012). Peer and self-reports of victimization and bullying: Their differential association with internalizing problems and social adjustment. Journal of School Psychology, 5o(6), 759-774. https//doi. org/10.1016/j.jsp.2012.08.004

Bradshaw, C. P., Sawyer, A. L., \& O'Brennan, L. M. (2009). A social disorganization perspective on bullying-related attitudes and behaviors: The influence of school context. American Journal of Community Psychology, 43, 204-220. https//doi.org/10.1007/s10464-009-9240-1

Buhs, E. S. \& Ladd, G. W. (2001). Peer rejection as an antecedent of young children's school adjustment: an examination of mediating processes. Developmental Psychology, 37, 550-560. https//doi. org/10.1037/0012-1649.37.4.550

Bussey, K., Luo, A., Fitzpatrick, S. in Kimberley, A. (2020). Defending victims of cyberbullying: The role of self-efficacy and moral disengagement. Journal of School Psychology, 78, 1-12. https//doi.org/10.1016/j.jsp.2019.11.006

Caravita, S. C. S., \& Cillessen, A. H. N. (2012). Agentic or communal? Associations between interpersonal goals, popularity, and bullying in middle childhood and early adolescence. Social Development, 21(2), 376395. https//doi.org/10.1111/j.1467-9507.2011.00632.x 
Caravita, S. C. S., Gini, G., \& Pozzoli, T. (2012). Main and moderated effects of moral cognition and status on bullying and defending. Aggressive Behavior, 38(6), 456-468. https//doi.org/10.1002/ab.21447

Catalano, R. F., Berglund, M. L., Ryan, J. A. M., Lonczak, H. S., \& Hawkins, J. D. (2004). Positive Youth Development in the United States: Research Findings on Evaluations of Positive Youth Development Programs. Annals of the American Academy of Political and Social Science, 591, 98124. https//doi.org/10.1177/0002716203260102

Cillessen, A. H. N. (2011). Sociometric methods. V. K. H. Rubin, W. M. Bukowski in B. Laursen (Ur.), Handbook of peer interactions, relationships, and groups (82-99). The Guilford Press.

Cillessen, A. H. N. (2011). Toward a theory of popularity. In A. H. N. Cillessen, D. Schwartz, \& L. Mayeux (Eds.), Popularity in the peer system (pp. 273299). The Guilford Press.

Cook, C., Williams, K. R., Guerra, N. G., Kim, T., \& Sadek, S. (2010). Predictors of bullying and victimization in childhood and adolescence: A meta-analytic investigation. School Psychology Quarterly, 25, 65-83. https//doi. org/10.1037/aoo20149

Craig, W. M., Pepler, D., \& Atlas, R. (2000). Observations of bullying in the playground and in the classroom. School Psychology International, 21(1), 22-36. https//doi.org/10.1177/0143034300211002

de Bruyn, E. H., Cillessen, A. H. N., \& Wissink, I. B. (2010). Associations of peer acceptance and perceived popularity with bullying and victimization in early adolescence. Journal of Early Adolescence, 30, 543-566. https// doi.org/10.1177/0272431609340517

DePaolis, K., \& Williford, A. (2015). The nature and prevalence of cyber victimization among elementary school children. Child \& Youth Care Forum, 44(3), 377-393. https//doi.org/10.1007/s10566-014-9292-8.

Eccles, J. S., Midgley, C., Wigfield, A., Buchanan, C. M., Revman, D., Flanagan, C., \& MacIver, D. (1993). Development during adolescence: The impact of stage-environment fit on young adolescents' experiences in schools and in families. American Psychologist, 48, 90-101. https//doi. org/10.1037/0003-066X.48.2.90

Eccles, J., \& Roeser, R. W. (2011). Schools as developmental contexts during adolescence. Journal of Research on Adolescence, 21, 225-241. https//doi. org/10.1111/j.1532-7795.2010.00725.x

Fredkove, W. M., Gower, A. L., \& Sieving, R. E. (2019). Association Among Internal Assets, Bullying, and Emotional Distress in Eighth Grade 
Students. Journal of School Health, 89(11), 883-889. https//doi.org/10.1111/ josh.12833

Garandeau, C., Lee, I., \& Salmivalli, C. (2014). Inequality matters: Classroom status hierarchy and adolescents' bullying. Journal of Youth and Adolescence, 43(7), 1123-1133. https//doi.org/10.1007/s10964-013-0040-4

Garandeau, C. F., Lee, I. A., \& Salmivalli, C. (2018). Decreases in the proportion of bullying victims in the classroom: Effects on the adjustment of remaining victims. International Journal of Behavioral Development, 42, 64-72. https//doi.org/10.1177/0165025416667492

Gini, G., Pozzoli, T. in Hymel, S. (2014). Moral disengagement among children and youth: A meta-analytic review of links to aggressive behavior. Aggressive Behavior, 40, 56-68. https//doi.org/10.1002/ab.21502

Gutman, L. M., \& Midgley, C. (2000). The role of protective factors in supporting the academic achievement of poor African American students during the middle school transition. Journal of Youth and Adolescence, 29, 223249. https//doi.org/10.1023/A:1005108700243

Holt, M. K., \& Espelage, D. L. (2007). Perceived social support among bullies, victims, and bully-victims. Journal of Youth and Adolescence, 36(8), 984994. https//doi.org/10.1007/s10964-006-9153-3

Jenkins, L. N., Demaray, M. K., Fredrick, S. S., \& Summers, K. H. (2016). Associations among middle school students' bullying roles and social skills. Journal of School Violence, 15(3), 259-278. https//doi.org/10.108o/1 5388220.2014 .986675

Juvonen, J. in Schacter, H. L. (2017). Bullying in school and online contexts: Social dominance, bystander compliance, and the emotional pain of victims. V A. Rutland, D. Nesdale in C. S. Brown (Ur.), The Wiley-Blackwell Handbook of groups processes in children and adolescents (pp. 317-332). Wiley.

Kendrick, K., Jutengren, G., \& Stattin, H. (2012). The protective role of supportive friends against bullying perpetration and victimization. Journal of Adolescence, 35(4), 1069-1080. https//doi.org/10.1016/j. adolescence.2012.02.014

Khoury-Kassabri, M., Benbenishty, R., Astor, R. A., \& Zeira, A. (2004). The contributions of community, family, and school variables to student victimization. American Journal of Community Psychology, 34(3-4), 187-204. https//doi.org/10.1007/s10464-004-7414-4 
Kljakovic, M., \& Hunt, C. (2016). A meta-analysis of predictors of bullying and victimization in adolescence. Journal of Adolescence, 49, 134-145. https// doi.org/10.1016/j.adolescence.2016.03.002

Košir, K. \& Japelj Pavešić , B. (2019). Analiza podatkov o medvrstniškem nasilju, pridobljenih $v$ raziskavah TIMSS 2011 in TIMSS 2015. Unpublished report. Pedagoški inštitut.

Košir, K., Klasinc, L, Pivec, T., Špes, T., Cankar, G., \& Horvat, M. (2020). Predictors of self-reported and peer-reported victimization and bullying behavior in early adolescents. The role of school, classroom and individual factors. European Journal of Psychology of Education, 35, 381-402. https//doi.org/10.1007/s10212-019-00430-y

Kowalski, R. M., Giumetti, G. W., Schroeder, A. N., \& Lattanner, M. R. (2014). Bullying in the digital age: A critical review and meta-analysis of cyberbullying research among youth. Psychological Bulletin, 140, 1073-1137. https//doi.org/10.1037/aoo35618.

Kowalski, R. M., Limber, S. P., \& McCord, A. (2018). A developmental approach to cyberbullying: Prevalence and protective factors. Aggressive and Violent Behavior, 45, 20-32. doi:10.1016/j.avb.2018.02.009.

LaFontana, K. M., \& Cillessen, A. H. N. (2010). Developmental changes in the priority of perceived status in childhood and adolescence. Social Development, 19(1), 130-147. https//doi.org/10.1111/j.1467-9507.2008.00522.x

Laninga-Wijnen, L., Harakeh, Z., Garandeau, C., Dijkstra, J. K., Veenstra, R., \& Vollebergh, W. A. M. (2019). Classroom popularity hierarchy predicts prosocial and aggressive popularity norms across the school year. Child Development, 90, 637-653. https//doi.org/10.1111/cdev.13228.

Lee, V. E., \& Smith, J. (2001). Restructuring high schools for equity and excellence: What works? Teacher's College Press.

Lerner, R. M. (2017). Commentary: Studying and testing the positive youth development model: A tale of two approaches. Child Development, 88, 11831185. https//doi.org/10.1111/cdev.12875

Ma, X. (2002). Bullying in middle school: Individual and school characteristics of victims and offenders, school effectiveness and school improvement. An International Journal of Research, Policy and Practice, 13, 63-89. https// doi.org/10.1076/sesi.13.1.63.3438

Marsh, H. W., Nagengast, B., Morin, A. J. S., Parada, R. H., Craven, R. G., \& Hamilton, L. R. (2011). Construct validity of the multidimensional structure of bullying and victimization: An application of exploratory 
structural equation modelling. Journal of Educational Psychology, 103, 701-732. https//doi.org/10.1037/aoo24122

Menesini, E. \& Salmivalli, C. (2017). Bullying in schools: The state of knowledge and effective interventions. Psychology, Health \& Medicine, 22, 240253. https//doi.org/10.1080/13548506.2017.1279740

Meter, D. J., \& Bauman, S. (2018). Moral disengagement about cyberbullying and parental monitoring: Effects on traditional bullying and victimization via cyberbullying involvement. The Journal of Early Adolescence, 38(3), 303-326. https//doi.org/10.1177/0272431616670752

Miller, D. T., \& Prentice, D. A. (1994). Collective errors and errors about the collective. Personality and Social Psychology Bulletin, 20, 541-550. https// doi.org/0146167294205011

Nishina A., Juvonen, J. (2005). Daily reports of witnessing and experiencing peer harassment in middle school. Child Development, 76, 435-450. https//doi.org/10.1111/j.1467-8624.2005.00855.x

Nocentini, A., Calmaestra, J., Schultze-Krumbholz, A., Scheithauer, H., Ortega R. in Menesini, E. (2010). Cyberbullying: Labels, behaviours and definition in three European countries. Australian Journal of Guidance \& Counselling, 2o(2), 129-142. https//doi.org/10.1375/ajgc.20.2.129

Olthof, T., Goossens, F. A., Vermande, M. M., Aleva, E. A., \& van der Meulen, M. (2011). Bullying as strategic behavior: Relations with desired and acquired dominance in the peer group. Journal of School Psychology, 49(3), 339-359. https//doi.org/10.1016/j.jsp.2011.03.003

Overton, W. F. (2015). Process and relational developmental systems. In W. F. Overton \& P. C. Molenaar (Eds.), Handbook of child psychology and developmental science: Theory and method (7th Ed., Vol. 1, pp. 9-62). Wiley. https//doi.org/10.1002/9781118963418.childpsy102

Pan, B., Zhang, L., Ji, L., Garandeau, C. F., Salmivalli, C., \& Zhang, W. (2020). Classroom status hierarchy moderates the association between social dominance goals and bullying behavior in middle childhood and early adolescence. Journal of Youth and Adolescence, 49, 2285-2297. https//doi. org/10.1007/s10964-020-01285-Z

Peras, I. (2019). Značilnosti učencev kot dejavniki spletnega medvrstniškega nasilja in viktimizacije. Magistrsko delo. [Students' characteroistics as factors of cyberbullying and cybervictimization. Master thesis.]. Oddelek za psihologijo Filozofske fakultete Univerze v Mariboru.

Pintrich, P. R., \& Schunk, D. H. (2002). Motivation in education: Theory, research, and applications (2nd ed.). Merrill Prentice Hall. 
Pouwels, J. L., Lansu, T. A. M. in Cillessen, A. H. N. (2018). A developmental perspective on popularity and the group process of bullying. Aggression and Violent Behavior, 43, 64-70. https//doi.org/10.1016/j.avb.2018.10.003

Pöyhönen, V., Juvonen, J., \& Salmivalli, C. (2010). What does it take to stand up for the victim of bullying?: The interplay between personal and social factors. Merrill-Palmer Quarterly, 56, 143-163. https//doi.org/10.1353/ mpq.0.0046

Rodkin, P. C., Espelage, D. L., \& Hanish, L. D. (2015). A relational framework for understanding bullying developmental antecedents and outcomes. American Psychologist, 70, 311-321. https//doi.org/10.1037/ao038658

Roeser, R., Eccles, J., \& Sameroff, A. (200o). School as a Context of Early Adolescents' Academic and Social-Emotional Development: A Summary of Research Findings. The Elementary School Journal, 100(5), 443-471. https//doi.org/10.1086/499650

Runions, K. C., Shaw, T., Bussey, K., Thornberg, R., Salmivalli, C., \& Cross, D. S. (2019). Moral disengagement of pure bullies and bully/victims: Shared and distinct mechanisms. Journal of Youth and Adolescence, 48(9), 18351848. https//doi.org/10.1007/s10964-019-01067-2

Saarento, S., Kärnä, A., Hodges, E. V., \& Salmivalli, C. (2013). Student-, classroom-, and school-level risk factors for victimization. Journal of School Psychology, 51, 421-434. https//doi.org/10.1016/j.jsp.2013.02.002

Salmivalli, C. (2014). Participant roles in bullying: How can peer bystanders be utilized in interventions? Theory Into Practice, 53(4), 286-292. https//doi. org/https://doi.org/10.1080/00405841.2014.947222

Salmivalli, C., Kaukiainen, A., \& Lagerspetz, K. M. J. (200o). Aggression and sociometric status among peers: Do gender and type of aggression matter? Scandinavian Journal of Psychology, 41, 17-24. https//doi. org/10.1111/1467-9450.00166

Salmivalli, C., Peets, K., \& Hodges, E. V. E. (2011). Bullying. In P. Smith \& C. Hart (Eds.), Blackwell handbook of childhood social development (pp. 510528). Wiley-Blackwell.

Sanders, C. E., \& Phye. G. D. (Ur.) (2004). Bullying. Implications for the classroom. Elsavier Academic Press.

Sandstrom, M., Makover, H., \& Bartini, M. (2013). Social context of bullying: Do misperceptions of group norms influence children's responses to witnessed episodes? Social Influence, 8, 196-215. https//doi.org/10.1080/155345 10.2011.651302 
Schacter, H. L., \& Juvonen, J. (2015). The effects of school-level victimization on self-blame: Evidence for contextualized social cognitions. Developmental Psychology, 51, 841-847. https//doi.org/10.1037/devooooo16

Sentse, M., Scholte, R., Salmivalli, C., \& Voeten, M. (2007). Person-group dissimilarity in involvement in bullying and its relation with social status. Journal of Abnormal Child Psychology, 35, 1009-1019. https//doi. org/10.1007/s10802-007-9150-3

Sijtsema, J., Veenstra, R., Lindenberg, S., \& Salmivalli, C. (2009). An empirical test of bullies' status goals: Assessing direct goals, aggression, and prestige. Aggressive Behavior, 35, 57-67. https//doi.org/10.1002/ab.20282

Smith, P. K., Mahdavi, J., Carvalho, M., Fisher, S., Russell, S., \& Tippett, N. (2008). Cyberbullying: Its nature and impact in secondary school pupils. Journal of Child Psychology and Psychiatry, 49(4), 376-385. https//doi. org/10.1111/j.1469-7610. 2007.01846.x.

Taštanoska, T. (Ed.). (2017). The education system in the Republic of Slovenia 2016/2017. Ministry of Education, Science and Sport of the Republic of Slovenia.

Taštanoska, T. (Ur.) (2020). Vzgoja in izobraževanje v Republiki Sloveniji, 2018/19. Ministrstvo za izobraževanje, znanost in šport.

Thornberg, R., Wänström, L., Elmelid, R., Johansson, A., \& Mellander, E. (2020). Standing up for the victim or supporting the bully? Bystander responses and their associations with moral disengagement, defender self-efficacy, and collective efficacy. Social Psychology of Education. Advance online publication. https//doi.org/10.1007/s11218-020-09549-Z

Tsaousis, I. (2016). The relationship of self-esteem to bullying perpetration and peer victimization among schoolchildren and adolescents: A meta-analytic review. Aggression and Violent Behavior, 31, 186-199. https//doi. org/10.1016/j.avb.2016.09.005

Yeager, D. S., Fong, C. J., Lee, H. Y., \& Espelage, D. L. (2015). Declines in efficacy of antibullying programs among older adolescents: Theory and a three-level meta-analysis. Journal of Applied Developmental Psychology, 37, 36-51. https//doi.org/10.1016/j.appdev.2014.11.005

van den Broek, N., Deutz, M. H. F., Schoneveld, E. A., Burk, W. J., \& Cillessen, A. H. N. (2016). Behavioral correlates of prioritizing popularity in adolescence. Journal of Youth and Adolescence, 45, 2444-2454. https//doi. org/10.1007/s10964-015-0352-7

Volk, A. A., Veenstra, R. in Espelage, D. L. (2017). So you want to study bullying? Recommendations to enhance the validity, transparency, and 
comparability of bullying research. Aggression and Violent Behavior, 36, 34-43. https//doi.org/10.1016/j.avb.2017.07.003

Wentzel, K. R. (2009). Student relationships with teachers as motivational context. In K. R. Wentzel \& A. Wigfiled, (Eds.), Handbook of motivation at school (pp. 301-323). Routledge.

Zych, I., Farrington, D. P., \& Ttofi, M. M. (2019a). Protective factors against bullying and cyberbullying: A systematic review of meta-analyses. Aggression and Violent Behavior, 45, 4-19. https//doi.org/10.1016/j.avb.2018.06.0o8

Zych, I., Ttofi, M. M., \& Farrington, D. P. (2019b). Empathy and CallousUnemotional Traits in Different Bullying Roles: A Systematic Review and Meta-Analysis. Trauma, Violence, and Abuse, 2o(1), 3-21. https//doi. org/10.1177/1524838016683456 